INTERNATIONAL JOURNAL OF FILM AND MEDIA ARTS (2021) Vol. 6, №. 3 pp. 67-84

(C) 2021 BY-NC

ijfma.ulusofona.pt

doi: 10.24140/ijfma.v6.n3.05

\title{
DANCE, LONG EXPOSURE AND \\ DRAWING: AN ABSURD MANIFESTO ABOUT \\ THE FEMALE BODY \\ ZEYNEP AKCAY*
}


INTERNATIONAL JOURNAL OF FILM AND MEDIA ARTS (2021) Vol. 6, №. 3

Zeynep Akcay is an animated filmmaker \& scholar focusing on experimental aesthetics and narrative strategies of animation in different environments. After working as an animator and teaching animation in Canada and Turkey, she currently leads animating major at Griffith Film School, Brisbane, Australia. Akcay has presented in numerous international conferences and her animations have been screened in Australia, US, Asia, Europe and in her native Turkey. www.zeynepakcay.com

\section{Corresponding Author}

Zeynep Akcay

z.akcay@griffith.edu.au

Griffith University - Griffith Film School

Lecturer - Animation Program

Brisbane, Australia 


\begin{abstract}
This paper summarises the evolution and production process of Kam, a long-exposure pixilation/2D animation film with a unique aesthetic approach that took three years to formulate and complete due to an iterative/fragmented production schedule. Kam, which means "shaman" in old Turkish, was conceived as a response to the rise of conservative and misogynist official discourse in Turkey, and it features a woman's fierce dance. For this film, Turkish dancer Sevinc Baltali's improvised performance was captured by the author using the technique of long-exposure photography. Condensing the motion of the dancer, the still frames created a flowing image on screen in which the dancer's body is sometimes hardly perceivable. The dance flow was then recreated to the music of Amolvacy, an underground New York band featuring a modern interpretation of tribal music. Finally, the manifesto of the film was reinforced by adding another layer, this time of primitive drawings by the author, on top of the images, creating a more pronounced expression of the anger and the rebellious energy of the female body.
\end{abstract}

This article argues that the unique aesthetics of the film attained at the end of an iterative and fragmented production process allowed a multi-layered liminal space for meaning to emerge. By elaborating on the relationship between the aesthetic approach, the political stance and the production methodology of this film, this article aims to demonstrate how animation can create an evocative and visceral experience that highlights and communicates what Herzog (2010) defines as "ecstatic truth".

Keywords: Female body, animated performance, pixilation, long exposure, dance 


\section{Introduction}

In 1989, seminal conceptual artist Barbara Kruger prepared a collage to support the Women's March on Washington protesting the new anti-abortion laws proposed by the conservative government at that time. Untitled (Your Body Is a Battleground) (Kruger, 1989) was a poster featuring a close-up of a woman's face split into positive and negative exposures. The overlaid caption, written in white on red in a bold font, reads: "Your body is a battleground". This work was a reminder that at stake in the so-called "pro-choice vs pro-life" conflict were in fact women's bodies, and any attempt to regulate them meant stripping women of their fundamental freedom.

The powerful "body as battlefield" metaphor is one that has persisted over the years. It is used to address a wide range of situations, varying from the unattainable beauty standards imposed on women to violent war crimes involving rape, torture and enslavement. For example, in Our Bodies, Their Battlefield: What War Does to Women, war reporter and author Christina Lamb (2019) documents survivors' stories around the world that reveal how rape is used as a weapon, while Body Battlegrounds: Transgressions, Tensions, and Transformations, edited by Chris Bobel and Samantha Kwan (2019), analyses the myriad ways social norms exert restrictions on individuals, indeed mostly on women. From limitations of reproductive rights to domestic violence, from normative control to war crimes, it would not be wrong to suggest that this metaphor successfully refers to the variety of control mechanisms over women's bodies around the world and across different cultures.

According to Didem Unal Abaday (2020), the rise of right-wing populism in Europe and over the world, especially in recent years, has brought a new wave of "familialist, pronatalist and anti-feminist" (2020) discourses in politics. Such discourse praises the family and positions women as the primary ones responsible for maintaining its functioning; encourages married women to give birth; and limits access to birth control and reproductive freedoms. The same patterns are easy to spot in contemporary Turkey, where the conservative turn in politics is becoming increasingly authoritative and misogynist. Starting with restrictive regulations against abortion, the aggressively sexist politics of the ruling Justice and Development Party under Recep Erdogan have recently culminated in Turkey's withdrawal from the Istanbul Convention, the world's first binding treaty to prevent domestic violence, despite the country being one of the first signatories on 11 May 2011 in Istanbul (Amnesty International, 2021). ${ }^{1}$ In this climate, the feminist movement in Turkey is very active. In fact, it can be described as "one of the largest and most impactful social collectives" (Ceylan, 2021), bringing women of different backgrounds together to fight issues such as domestic abuse, femicides, everyday sexism and the policies that sanction them.

Kam, the long-exposure pixilation/2D animation film that is the subject of this article, was inspired by the feminist movement's defiance against conservative policies' attempts to control women and the female body. The movement has typically used a humorous, joyful and fierce discourse while resisting the oppressive politics and the fixed roles that are imposed on womanhood, and Kam tries to create such a mood via a woman's dance on screen. Kam, which means "shaman" in old Turkish, draws on paganist cultures' relationship with dance, where the body of the shaman is believed to transform and embody different forms of energy. For this film, Turkish dancer Sevinc Baltali's improvised performance was captured by the author through long-exposure photography. Condensing the motion of the dancer, the still frames creates a flowing image on screen in which the dancer's body sometimes becomes hardly perceivable. These frames were brought together to create a new, animated dance flow to the music of Amolvacy, an

1 It is worth noting here that this treaty, accused of dictating its "subversive gender ideology" on society's traditional values, had faced similar reactions from other conservative governments such as Slovakia, Poland, Bulgaria and Hungary. 
underground New York band that published their work with a creative commons license. The song, which features explosive female vocals, was chosen especially because of its modern interpretation of tribal themes. Finally, the film's manifesto was reinforced by the author adding another layer to the image, consisting of "doodly" hand-drawn animation. Overall, it took three years to complete this film because of involuntary interruptions, which resulted in an iterative production process.

This article analyses how different stages of production in Kam led to the unique aesthetics of the film, which allowed a visceral expression of the fierce female energy that I, as the author of the film, needed to reaffirm in the face of oppressive discourses surrounding women. To do so, it focuses on the specific way Kam created different layers of expression, integrating dance, long-exposure photography, and my "2D intervention" to the frames. The article argues that the iterative production process in Kam, resulting from the several challenges at personal and artistic levels, ended up transforming and re-transforming the performance, which allowed a primitive liminal space to be represented on the screen. By highlighting the connections between the political stance of myself as author, the production methodology and the unique aesthetics of this film, I hope to demonstrate how animation can be a powerful medium in activism, not in terms of directly stating, discussing or narrating specific topics, but in terms of displaying and communicating what Herzog (2010, p. 9) calls "a deeper stratum of truth-a poetic, ecstatic truth, which is mysterious and can only be grasped with effort" attained "through vision, style, and craft".

\section{Kam's “Non-Ecstatic” Truth}

In a country where the "Westernisation" project of the modern secular republic challenged centuries-long traditions and identities, secular Turkish women have been dealing with manifold manifestations of patriarchy originating from both Eastern and Western cultures. Raised in a secular, relatively progressive middle-class family in Turkey, I was encouraged to pursue my own interests in life and to become an independent woman, but when it came to sexual freedom or bodily expression, I was restricted by the limits that the society drew for any "decent modern republic woman"-financially independent yet devoted to family, assertive but not "deviant", behaving and dressing appropriately at all times, in attire that is not Islamic but not too revealing either. Meanwhile, the official politics of the government also took a regressive direction.

The ruling Justice and Development Party changed its "conservative democratic" image that at first seemed to create a liberal space for different worldviews to coexist and turned to its Islamist roots, adopting increasingly authoritative and misogynist discourses and policies. Devran Gulel, in an article where she analyses the President of Turkey Recep Erdoğan's declarations after the general election of 2011, affirms that his "discourse on women has become an important tool to reproduce and strengthen the patriarchal social order and patriarchal understanding of gender relations" (Gulel, 2020, p. 21), defining "appropriate womanhood in a way that embraces propriety and subordination" (Gulel, 2020, p. 14). For example, he has publicly made affirmations about how every woman "should have at least three children" and how "a woman who rejects motherhood, who refrains from being around the house, however successful her working life is, is deficient, is incomplete" (Agence France-Presse, 2016). These discourses also condemn the feminist movement as marginal and alienates activities of some "showpeoples" (Gulel, 2020, p. 18). Official policies support the discourse, varying from limiting women's access to abortion and C-sections to withdrawing from the Council of Europe Convention on Preventing and Combating Violence against Women and Domestic Violence, known as the Istanbul Convention. This convention was signed in Istanbul in 2011, and Turkey was the first member state to ratify it with a unanimous vote in parliament, with the support of the same ruling party (Justice and Development Part - Adalet ve Kalkinma Partisi, AKP). 
Erdoğan even praised the convention "as evidence that Turkey was a leader in gender equality" (Yalcinalp, 2021). However, as the party became more vulnerable politically and Erdoğan sought to consolidate his conservative and Islamic support base, the convention contradicted the values hold by these fractions, because it "undermined traditional family values" by "encouraging divorce" and by obliging the signatories to protect victims from discrimination regardless of their sexual orientation or gender identity. As a result, Turkey withdrew from Istanbul Convention by a midnight presidential decree, one of the staples of the Erdoğan regime.

As mentioned earlier, the feminist movement is one of the largest and most visible oppositional forces in Turkey, with "women put[ting] aside their social, cultural and political differences in the fight against male violence" (Ceylan, 2021). Its campaign against the withdrawal from the Istanbul Convention found significant support through social media and its main motto, "Istanbul Convention Saves Lives", was shared by millions of women around the world.

The struggle against femicides and domestic abuse is an active issue that is being supported through legal, social campaigning and financial support activities of different initiatives, such as the "We Will Stop Femicide Platform" (Kadin Cinayetlerini Durduracagiz Platformu). Yearly night marches are also a staple of the movement's activities, bringing feminists from all ages, background and genders together. Every year on the evening of 8 March (International Women's Day), the women's movement joins forces with the LGBTI+ movement, and thousands of women gather in Istanbul to celebrate solidarity and to protest oppressive sexist policies. Inspired by the Reclaim the Night movement in England, the march takes place at night in order to defy the common notion of "women should not go out on the street at nights". It shares a joyful and carnivalesque air with the LGBTI+ movement, defying and making fun of the conservative and oppressive discourses, celebrating sexuality and freedom. In 2021, the march was held for the nineteenth year, despite the police interventions that took place in earlier years and the detentions that followed. The opening statement read: "With our laughter, our anger, our rebellion and our resistance, we are here, at the 19th Feminist Night March. We stand side by side and we are strong thanks to our feminist solidarity" (ANF News, 2021).

\section{Pre-Production of Kam}

Inspired by the defiant and fierce tone of the feminist movement against any attempt to oppress women, Kam started to take shape as a woman's unapologetic dance on screen where she celebrates and joyfully exposes her body by affirming her female energy. Dance, with its intrinsic link to one's body and its immediate expressions, appears to be the most appropriate tool for embodying the visceral experiences that a woman undergoes throughout her life.

Another inspiration for this film were the ritual performances, which are considered to be exempt from everyday/regular normative reality by bringing forth the wilder, deeper, repressed aspects of society. According to Richard Schechner (2017, p. 52), rituals have manifold functions:

Rituals are collective memories encoded into actions. Rituals also help people (and animals) deal with difficult transitions, ambivalent relationships, hierarchies, and desires that trouble, exceed, or violate the norms of daily life. Play gives people a chance to temporarily experience the taboo, the excessive, and the risky. You may never be Oedipus or Cleopatra, but you can perform them "in play." Ritual and play lead people into a "second reality," separate from ordinary life. This reality is one where people can become selves other than their daily selves. When they temporarily become or enact another, people perform actions different from what they do ordinarily. Thus, ritual and play transform people, either permanently or temporarily. 


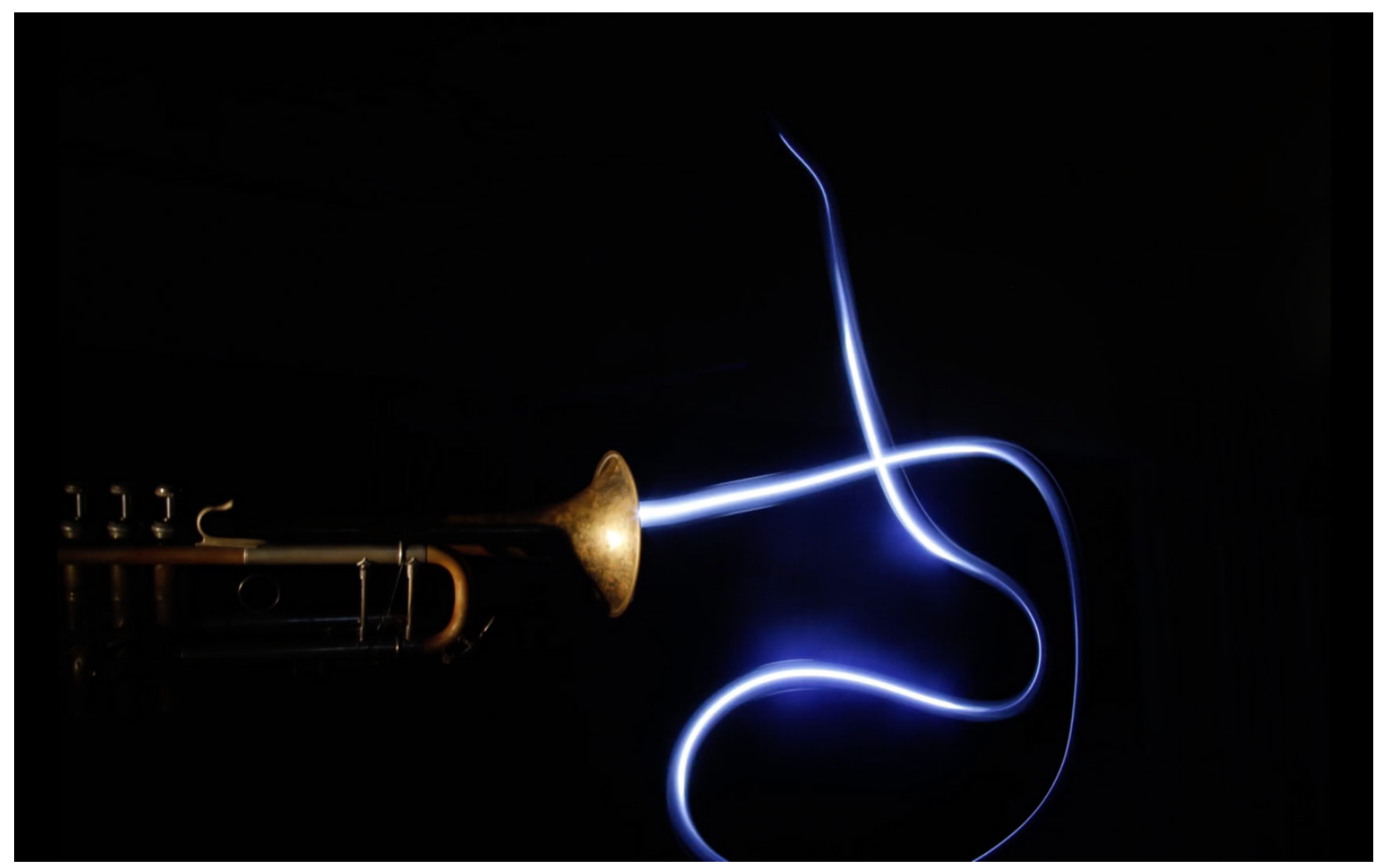

Fig. 1 Still from Jazz Motion (Akcay, 2016).

Therefore, with the vision of creating a ritualistic space where a woman would embody a certain repressed inner energy via dance and transformations, I started exchanging ideas and similar experiences of being a woman with my collaborator, dancer Sevinc Baltali. Discussing themes of wild archetypes of women, especially from Women Who Run with the Wolves (Estes, 1989) and how the idea of primal female potency was intimidating to the male fantasy of power and control, Baltali and I built a common ground of understanding. After our exchanges, I drafted an initial choreography featuring a woman passing through different stages, "transforming" into different animals, and finally becoming an omnipotent energy form, moving fast, and exploding in different parts of the frame. The choreography consisted of various poses alluding to wild animals with fluid passages between them. These passages would occur more and more frequently, finally giving way to more abstract compositions consisting of movement traces. Although later abandoned and replaced by the improvisation of the dancer, a few poses from the original choreography remain in the final film.

From the pre-production phase, long-exposure photography was always one of the building blocks of the specific aesthetics of the film. Kam is the third piece in a series of works where I have investigated the integration of long-exposure photography in pixilation and stop-motion filmmaking. For instance, in Jazz Motion (Akcay, 2016), I used long exposure to capture lights (a technique which is also called light-painting) to allude to the improvisational energy of jazz music (Fig. 1). In Instable (Akcay, 2017), two actors portray 


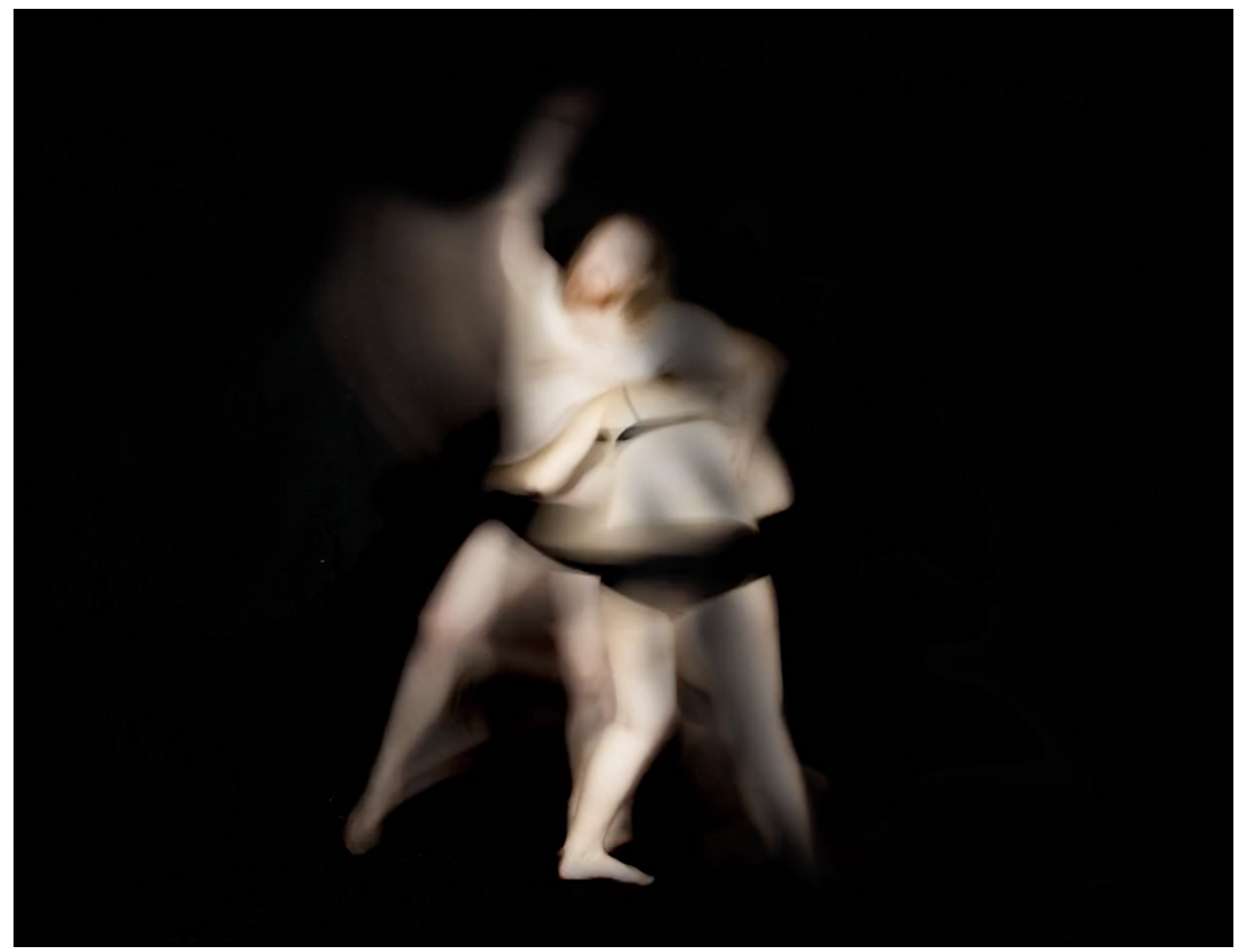

Fig. 2 Still from Instable (Akcay, 2017).

an intermittent "mating dance" in pixilation, integrating static poses intertwined with fluid passages between them (Fig. 2). Inspired by Magali Charrier's Peace Starts with Me (2011) where she used the long-exposure technique combined with ink drawings to create a dissociated, transforming and recomposing sense of body in the dancer, I initially conceived Kam around highlighting the body as a transitioning entity via the interplay of static and fluid poses, enabled by long-exposure pixilation.

\section{Long Exposure}

In the first years of photography, long exposure was an optical necessity used to expose the photographic surface with enough light to be able to form an impression. The oldest surviving photograph, View from the Window at Le Gras (1826) by Joseph Nicéphore Niépce, had to be exposed for over eight hours to be able to imprint the vision in front of the window. During this period, the time needed to compose 
a photograph was considered as an undesirable feature of the machine, limiting the possibility of capturing a clear image if the subjects were in motion. However, this feature has subsequently been used expressively in different contexts. For example, in his City of Shadows series (1993), Alexey Titarenko portrayed the vulnerability and temporality of humans as traces against the backdrop of a historical city in a collapsing Soviet Union regime. At the Museum of Modern Art (MoMA) in New York, Michael Wesely (2003) documented a historical phase in MoMA's life. "Instead of a momentary glimpse presented as fact and just as quickly consumed, Michael Wesely's photographs for MoMA offer an experience in which past and present are intertwined elements of an evolving proposition," wrote Sarah Hermanson Meister (2004) in her essay for the book the Museum published to accompany the exhibition Open Shutter.

In my own photographic practice, I have used the long-exposure technique to capture traces of movement in a manner akin to Hengki Koentjoro's Tenggerese Horseman (2019). To me, long exposure captures not only a visual likeness of the subject, but also its movement, embedded gesture and kinetic energy. As an animator, I find this kinetic energy fascinating and utterly narrative, for the subject is caught in the process of moving, changing, and becoming. In this transitory, liminal phase, the subject is seen between its previous and next form.

"Liminal" and "liminality" are terms derived from the Latin limes ("threshold") and although they originate from the field of anthropology, today we can find them in a wide array of social sciences and arts, anthropology, sociology, psychology, economy, geography, literature, architecture and performance studies, to name a few. They designate the in-between, transitory states that exist on the thresholds. French anthropologist Arnold van Gennep is attributed as the person who coined the term "liminal" in his Les Rites de Passage
(1909, as cited in Schechner, 2017). While examining rites of passage in traditional non-Western societies, van Gennep identified three phases: separation from the old identity/ group; the middle or liminal phase; and reintegration to the new identity/group. For example, a girl who is initiated to womanhood but is not yet a woman would be in the liminal or middle phase. British cultural anthropologist Victor Turner, fascinated by the liminal phase's potential in rituals to create new situations, identities and social realities, redefined the term for modern societies:

Liminal entities are neither here nor there; they are betwixt and between the positions assigned and arrayed by law, custom, convention, and ceremonial. As such, their ambiguous and indeterminate attributes are expressed by a rich variety of symbols in the many societies that ritualize social and cultural transitions. Thus, liminality is frequently likened to death, to being in the womb, to invisibility, to darkness, to bisexuality, to the wilderness, and to an eclipse of the sun or moon. (Turner, qtd in Schechner, 2017, p. 66)

Therefore, we can consider liminal phases as the exact times and spaces where transformations occur and where the "betwixt and between" are expressed. Although these descriptions/affirmations deal mostly with social identities and ritualistic practices and not visual aesthetics, it is not a long stretch to suggest that long-exposure photography would be one of the most appropriate aesthetic approaches to express the state of "being in between" in visual form. With its unfixed form between the previous moment and the next moment, the most dominant features of long-exposure photography are the flux, the kinetic energy and the expression of becoming. Within the single image, it is possible to find the connection between the before and after, and I find in this unfixed state a powerful narrative potential where anything can 
happen. Therefore, as a visual tool, it is powerful in its ability to capture liminal qualities.

As I was striving to make a film that evokes an emotional response to the internal, uncontainable energy of the female body as well as encapsulating the desire to defy any attempt to define, regulate or impose a fixed identity on women, the choice to employ long-exposure photography seemed apt.

\section{Live Performance of the Dancer ...and of the Animator}

As I was residing in Brno, Czechia, and Baltali was living in Izmir, Turkey, our conversations during the pre-production phase took place online, and I had to wait until I travelled to Turkey to be able to start the filming. With Baltali working in a day job and me being in a transitory state between two countries, we were only able to reserve three days for the filming process. We started the first day with applying the ideas of the original choreography to the classical pixilation method, which consisted of Baltali keeping still while I took the picture. However, it soon became clear that the frame-by-frame approach disrupted the dancer's flow, and the energy of the movement was lost between each pause. Even during the long-exposure shots, Baltali had to move in specific directions and stop at specific moments to create the traces of movement in desired ways, which also proved to be rather difficult and counter-intuitive.

Pierre Hebert (1990), while recounting his experience of working with dancers in animated works, draws out the fundamental differences between the "danced motion" and "animated motion". For him, although "Both dance and animation deal with the artistic expression of motion" (Hebert, 1990), in animation, the instrumental process that resides between the concept of motion and the illusion on the screen effaces the body of the animator. In dance, however, the motion comes directly from the dancer's body and from the kinetic energy it expends at the time of creation.
Although I will later argue that the specific process of capturing the dancer's improvisation resulted in another type of "animator's performance", for now I would like to focus on the dancer's performance. In Kam, the pixilation process that we tried to follow resulted in destroying the dancer's flow, hence stripping her from her primary material of expression, agency and performance by reducing her to a human puppet. This also resulted in losing the visceral kinetic energy that was critical to capture in Kam.

Velleda C. Ceccoli (2012), while discussing German choreographer Pina Bausch's work, affirms that her work's power lies in its engagement with the internal experiences of the dancers. Bausch's specific process consisted of asking her dancers to create their individual movement to highlight an emotion and building the performance around this individual movement. Bausch's Tanztheater ("dance theater") originates with dancers' subjectivity, embodying their own experience and emotions through movements that they innovate. This originality creates a significant departure from the classical choreographic approach where dancers' bodies become tools, objects of aesthetic execution rather than embodiments of human experience. According to Ceccoli (2012), in this way, Bausch "was building emotional mind-body circuits created in relation to another, and in her dances those circuits are alive and firing away between the dancers and us".

With this understanding, confident that Baltali and I had had enough discussions and shared a similar understanding about the underlying ideas and emotions of Kam, I decided to embrace another method and asked the dancer to express her interpretation of the themes in an improvised way. This allowed the kinetic energy to be undisrupted, and via the improvisation, her body was able to create new connections, gestures and expressions while being in movement. Adding a prop-in this case, a big scarf-helped to augment and emphasise the movements even further. As result, the original choreography, consisting of stable poses with fluid 


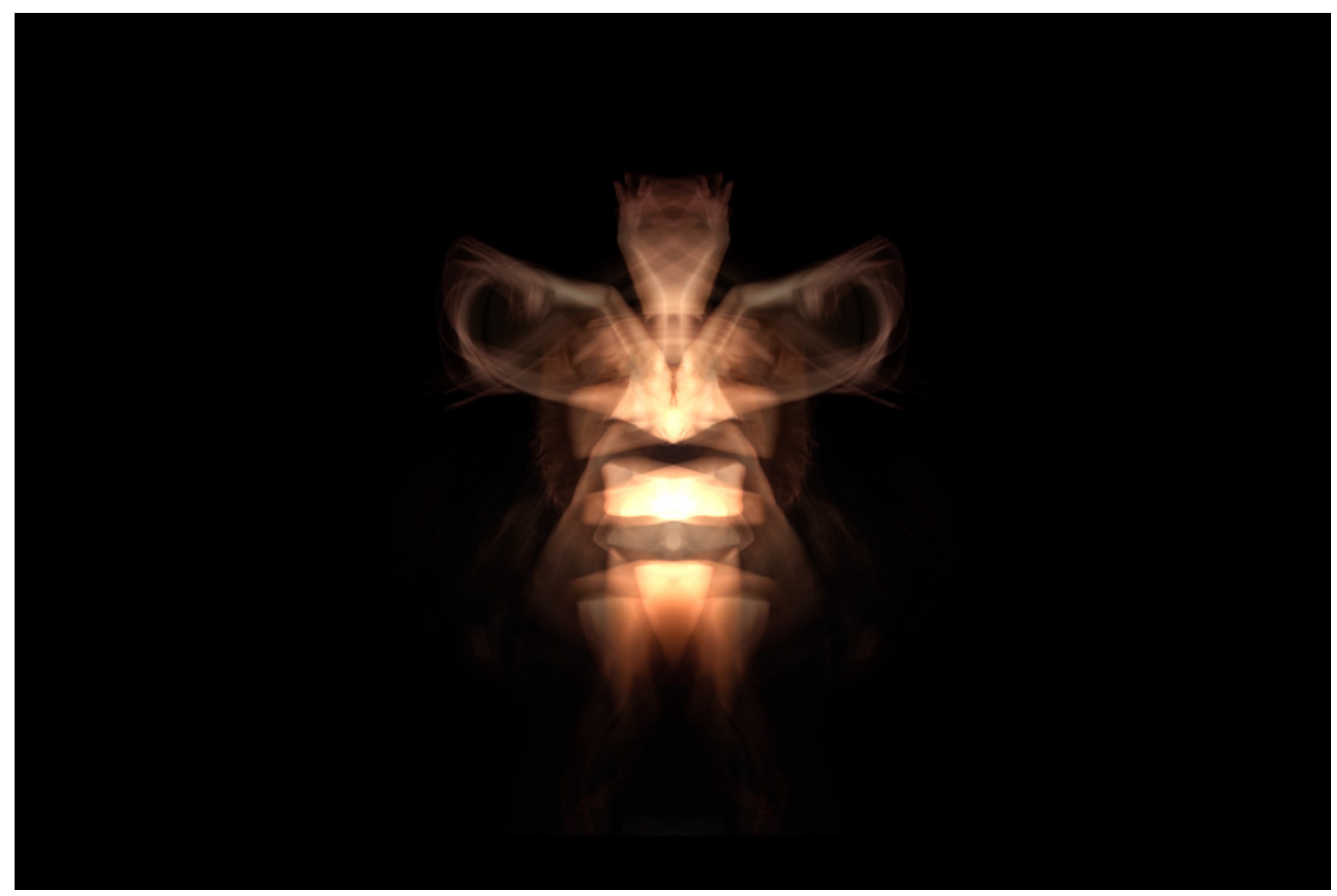

Fig. 3 Still from Kam, 1st iteration.

transitions in-between them, was abandoned to the benefit of more long-exposure photographs, creating a flow that consisted of more "liminal", in-between, transitory representations on the screen.

My role during this improvisation was to capture the "meaningful moments" in sync with the dancer's movements, sometimes even with the anticipation of what would come next. With the exception of a few pauses where I asked the dancer to re-perform some parts of her improvisation to better articulate the gesture or to better capture the moment, this flow was uninterrupted and fuelled by spontaneous decisions and variations. In this sense, the improvisation was two-fold, with the live performance of the dancer in front of the camera and the "performance" of the animator behind the camera merging in one flow.

\section{Recreating the Flow}

The improvisation of the dancer resulted in more than 1130 individual frames, consisting mostly of discontinued, fragmented gestures (apart from the initial choreography). After moving and settling into a different country which resulted in another involuntary delay of almost seven months, I was able to return to these frames to create a new flow. 


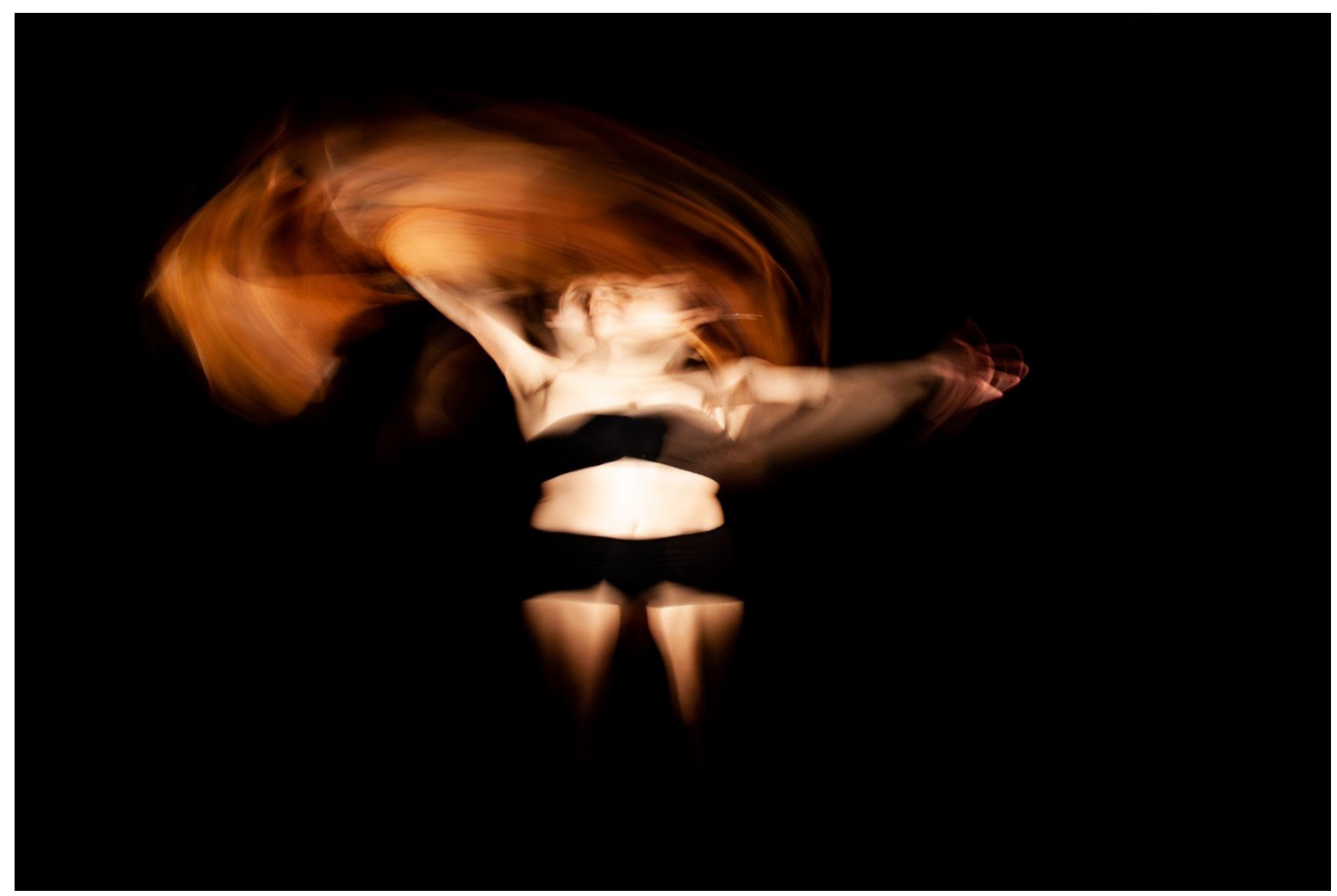

Fig. 4 Still from Kam, 1st iteration.

This hiatus, however involuntary, helped me to approach the material with fresh eyes and to see new connections within the frames. At times, building these connections was guided by the continuity of movement (although part of different gestures); at times, the colour; and at other times, the narrative. It became also clear that the unifying and structuring unit of this film should be the music and the sound design.

In accordance with the theme of the "wild woman" archetype, my search for an appropriate music track was driven by tribal influences. Although the idea of portraying a primal dance was inspired by the paganist heritage of pre-Islamic Turkish culture, I did not want the film to be specific to a certain geography's folklore or history, nor to have the spiritual ramifications usually attributed to shamanic dances. In line with this approach, the music I was looking for had to bring some modern interpretation to the tribal influences. Amolvacy's "Hu Hu Kus" was thus the most appropriate song, with its raw energy and its fierce female vocals uttering barely recognisable words, offering a modern approach to tribal storytelling.

From the available frames and with the guidance of Amolvacy's music, a new animated flow appeared with a progression from still to kinetic, featuring several transformations that resulted in the erasure of the body, leaving only the traces of the motion and colour on the screen. 
At this stage, another delay of eight months occurred due to full-time job requirements. Upon my return to the film, I found that although the flow was clear and aesthetically pleasing, the manifesto-the "ecstatic truth" that I needed to express through this film-was missing. I felt like the angry energy, the urge to scream women's uncontainable and irrepressible powerful existence that drove me to create this film in the first place, was lost among the pleasing transformations and surprising visual occurrences. Therefore, I decided to intervene the images by using 2D drawings.

After a research phase experimenting with different kind of lines and definitions, I decided that the hand-drawn lines on top of the dancer's images did not need to be realistic or complementary to the frames' harmonious aesthetics, but should rather be raw, doodle-ish, and even recklessly disruptive. In a way, they manifest their own absurdness by playing with the mismatch with the real images, sometimes even becoming an entity on their own. In that sense, this intervention should not be considered as a rotoscoping act, but rather an interpretative and reflective process, reflecting the author-viewer's response to the images seen on the screen. This way, the $2 \mathrm{D}$ animation layer self-reflectively highlights the animator's comment about the female body and the emotions that the dance flow evoked.

This position led me to determine possible moments of intervention: similar to a stream of consciousness, the drawings were sometimes inspired by the traces of movement, sometimes by the specific rhythm in the music, and sometimes, by the narrative intentions. For example, at $02 \mathrm{m02sec}$, the lines follow the scarf's trajectory and complement it in an explosive way within the frame (Fig. 6), in line with the music's beats, while at 24sec, when the dancer poses like a" monster", the lines depict a naked shaman with long nails superimposed with the dancer's image (Fig. 7), augmenting and amplifying the pose's underlying emotion. At 50sec, after the dancer disappears, the lines become independent and take the stage

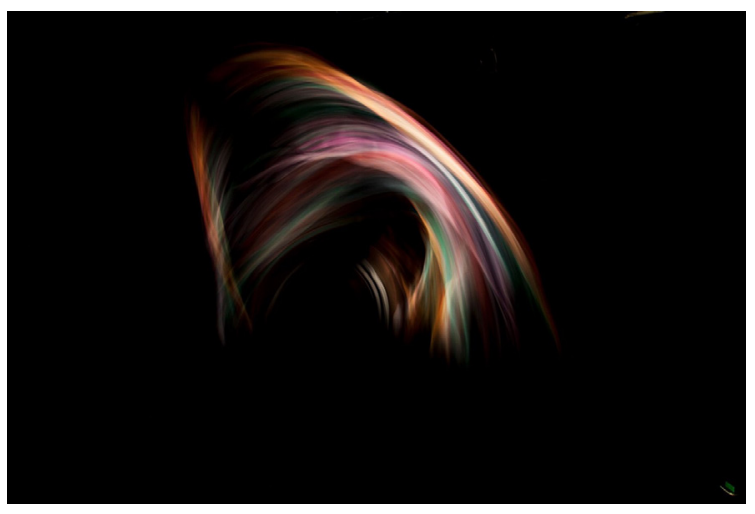

Fig. 5 Still from Kam, 1st iteration.

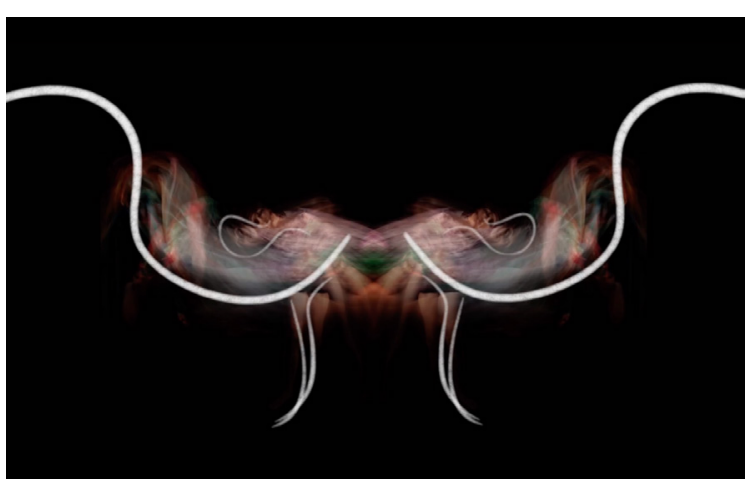

Fig. 6 Still from Kam, 2nd iteration.

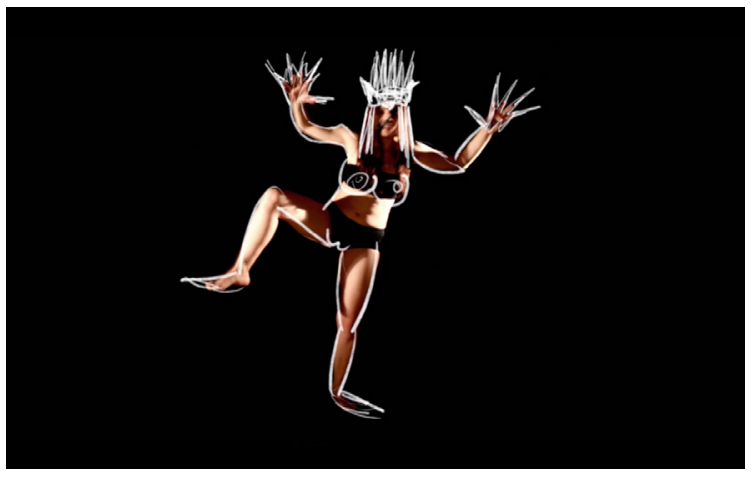

Fig. 7 Still from Kam, 2nd iteration. 


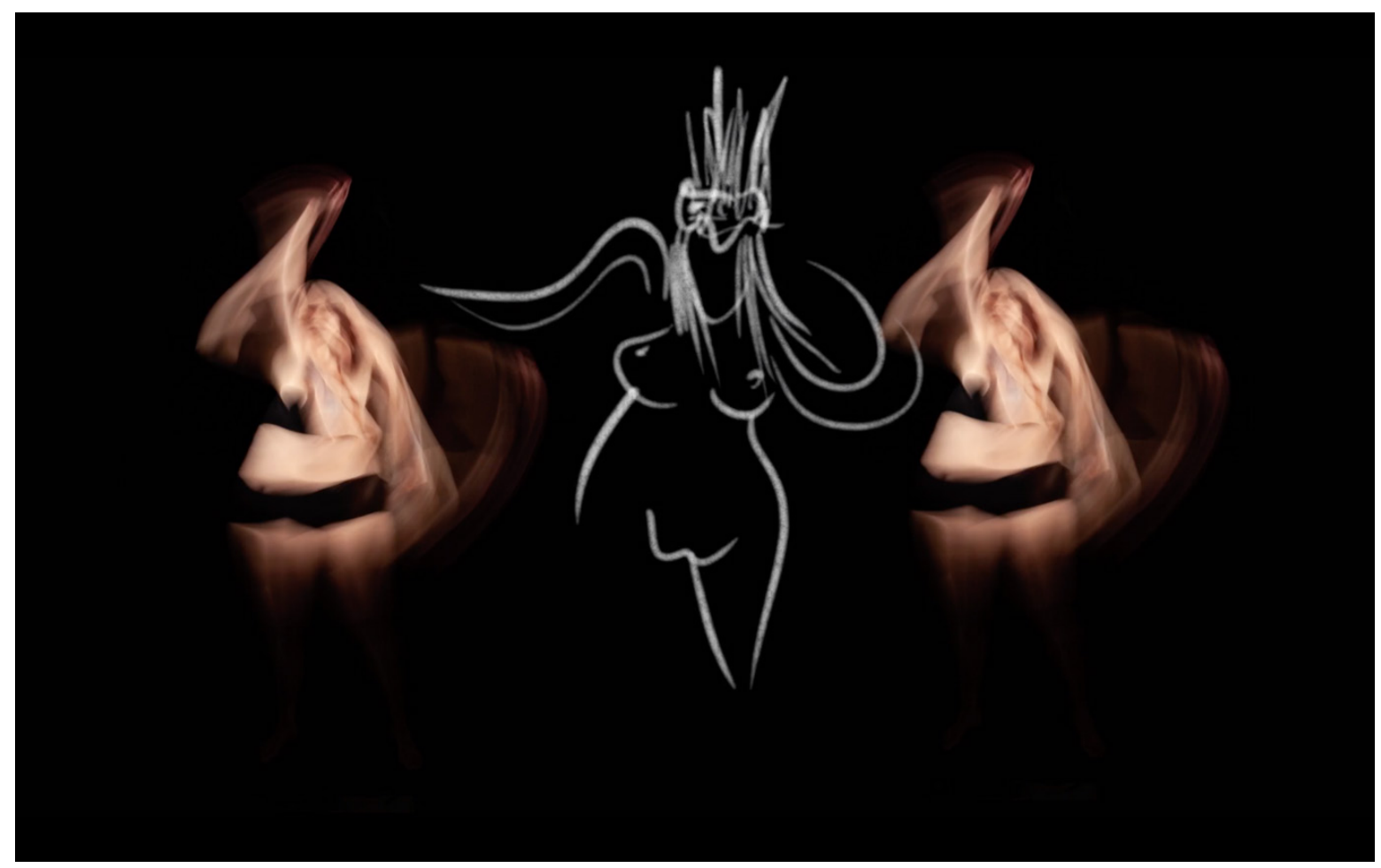

Fig. 8 Still from Kam, 2nd iteration.

in a naked dance (Fig. 8), celebrating its own life and body. Finally, similar to the progression of the first iteration, where the body eventually transforms into traces of colour and pure movement, the drawings become more and more doodle-ish and irreverent (Fig. 9).

The result is two entities (the dancer, captured in long-exposure photographs and the hand drawings of the animator), complementing, splitting, and reuniting in a playful and fierce dance on the screen. The drawings sometimes seem to challenge and sometimes harmoniously follow the movements of the dancer, revealing or augmenting the emotion underneath the gestures and the beats.
Comparing this "enhanced" version to the earlier flow featuring only the long-exposure photographs, it is possible to discern another important specific aspect of animation at work here. Eisenstein, in his writings about Disney cartoons, talks about some instances where "contour, the outline of a drawing-its generalising line, suddenly begins to take on an independent life, independent of the figures themselves, the object themselves" (Eisenstein 1986, p. 59). To Eisenstein, this dissection of contour and image is one of the characteristics of "primitive and primordial thought", where "the consciousness of the child is not yet capable of comprehending the unity of the whole and the part, and the part separately from the whole" (1986, p. 59). 


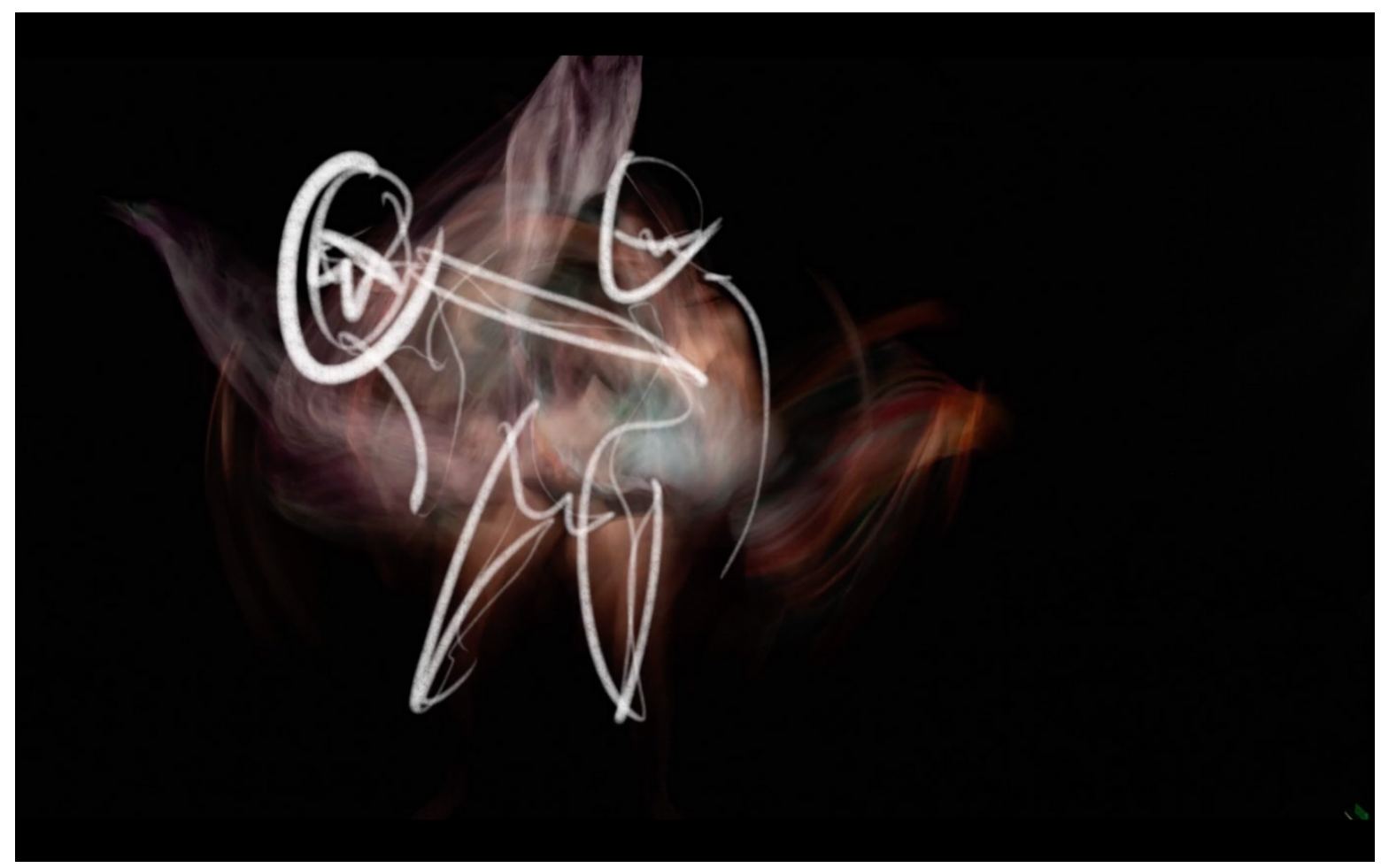

Fig. 9 Still from Kam, 2nd iteration.

Animation's capacity of creating this pre-logic state existing "beyond good and evil" is the main reason behind Eisenstein's fascination with Disney cartoons. According to him, in the Disney world, everything is bound to "one's fantasy and will.... a world of lines and colours which subjugates and alters itself to your command. You tell a mountain: move, and it moves. You tell an octopus: be an elephant, and the octopus becomes an elephant. You tell the sun: "Stop"-and it stops" (Eisenstein, 1986, p. 3). He calls the capacity of these defined forms to transform into other defined forms at any time as "plasmaticness" for they contain the potential of a "primal protoplasm, not yet possessing a 'stable' form, but capable of assuming any form" (Eisenstein, 1986, p. 21).
At the time of its first definition in 1830s, the term "protoplasm" designated "the ground substance of living material and, hence, responsible for all living processes" (Britannica, 2015). Although the term is somewhat unpopular in modern biology today, "protoplasmic streaming", another term describing the movement of the fluid substances within a living cell to transport nutrients, proteins and organelles pithing cells, is still commonly used (Britannica, 2015).

It can be argued that the doodle-ish, undefined lines superimposed on the long-exposure photographs serve as a "protoplasmic streaming" in the narrative, transporting the sentiments that were the main driving forces in starting to make such a film: to express the female fierceness and the 
potent energy of the female body that rejects to conform to any impositions upon it.

\section{Conclusion}

The aim of this article has been to demonstrate how an animated film can treat a socially and personally resonant matter in a visceral way, by describing the different stages of production of the long-exposure pixilation/ 2D animation film Kam. This film started with the need to affirm the intrinsic power of the female body against the regressive discourses and politics emerging in Turkey, which, as a woman, made me feel personally attacked.

During the production process, the original structure underwent several modifications to address the technical, logistic and artistic challenges that emerged. First, the classical pixilation method was abandoned to achieve a more spontaneous and expressive dance improvisation. The capturing of this improvisation created a two-fold performance: the dancer's performance in front of the camera generated by her body's movements and the animator's performance behind the camera, created in response to the dancer's movements. Long-exposure photography was crucial in capturing and condensing the traces of motion in individual frames, allowing a liminal space to be represented on the screen, where the body of the dancer is constantly seen in transition, in between, in "becoming" states.

The second change was the creation of a new flow, which, after a delay, was made possible by revisiting individual frames and finding new connections between them. At this phase, the music was one of the most important structuring elements, with its fierce female vocal and modern interpretation of shamanist rituals.

The final change, again after another period, was the intervention of the animator via the primitive drawings on top of images, which sometimes became an entity on its own, creating a new, more pronounced layer of expression.

I argue that the constant interplay between the two entitiesthe "liminal" photographs of the dancer and the doodle-ish, stream-of-consciousness lines of the author-serves to move viewers to a more primal state of thought, which, besides offering an audio-visual spectacle feeding from protoplasmic omnipotence, also creates a liminal space for meaning, emphasising the potency and the "ecstatic truth" of the female body.

The audience responses to Kam filmed as part of the Wildsound Film Festival in December 2020 supports this argument:

I love how the single dancer is immersed in digital flame fire and color in addition to these dancing white lines that create the female body and a couple times a headdress. I just love the spirit-like essence to this film and the high-pitched female war cry and the strong drum beat are extremely effective in addition to these violin strains I can really sense the anger towards the pilgrims and their mother ruler. (Wildsound Festival, 2020, 0:56)

I wasn't able to take my eyes off the dancer and there were very strong background voices throughout the entirety of the film which I really appreciated. I also liked watching the dancer transform and like become different figures-different figures would take over what we just saw and that worked really well because you're always wondering what we're going to see next and what's going to happen next. (Wildsound Festival, 2020, 4:52)

It feels chaotic but it definitely has its own uh internal sense of logic and that's what I think makes the piece work so well because if not it would just feel very random. (Wildsound Festival, 2020, 6:16) 
Although this film does not directly address the specific discourses about women and female body that I vehemently objected to, I believe Kam successfully represents the "ecstatic truth" that I was seeking to express on the screen because of its specific aesthetics and production processes. In this film, beside watching the spectacle of transformations and interplay of "contour" and liminal representations, the viewer also witnesses a visceral expression of the potency of female anger in rejecting any fixed form/identity.

\section{References}

Abaday, D. U. (2020, February 25). Muslim feminists' borderland positions in an authoritarian populist regime: The case of Turkey. Conference session. University of Helsinki, Helsinki, Finland.

Agence France-Presse. (2016, June 6). Turkish president says childless women are 'deficient, incomplete. The Guardian. https://www.theguardian.com/world/2016/jun/06/turkish-president-erdogan-childless-women-deficient-incomplete Akcay, Z. (Dir.). (2016). Jazz motion [Film].

Akcay, Z. (Dir). (2017). Instable [Film]. Festival Voix des Femmes.

Amnesty International. (2021, May 7). Here's why the Istanbul Convention saves lives. https://www.amnesty.org/en/latest/ news/2021/05/heres-why-the-istanbul-convention-saveslives/

ANF News. (2021, March 8). Feminist night march in Istanbul. https://anfenglish.com/women/feminist-night-march-in-istanbul-50503
Bobel, C., \& Kwan, S. (Eds.). (2019). Body Battlegrounds: Transgressions, Tensions, and Transformations. Vanderbilt University Press.

Britannica, T. Editors of Encyclopaedia (2015, January 29). Protoplasm. Encyclopedia Britannica. https://www.britannica.com/science/protoplasm

Ceccoli, V. C. (2012). Feeling Pina: How the choreographer moved people. Psychology Tomorrow Magazine. https://psychologytomorrowmagazine.com/feeling-pina-how-the-choreographer-moved-people/

Ceylan, A. (2021, March 9). Witches and rainbows: Women take Istanbul in all their colors on March 8. DuvaR English. https://www.duvarenglish.com/witches-and-rainbows-women-take-istanbul-in-all-their-colors-on-march-8-news-56556

Charrier, M. (Dir.). (2011). Peace starts with me. PUMA Peace [Film].

Eisenstein, S. (1986). Eisenstein on Disney, trans. and ed. J. Leyda. Chicago: Seagull Books.

Gulel, D. (2020). Patterns of misogyny in Turkey's contemporary political discourse: An analysis of the presidential speeches. Nuovi Autoritarismi e Democrazie: Diritto, Istituzioni, Società, 2(1): pp. 1-23. https://doi.org/10.13130/2612$\underline{6672 / 13436}$

Hebert, P. (1990). The portrayal and presence of the body in animated films. Paper presented at Society for Animation Studies Conference Ottawa, October. http://pierrehebert. com/en/publications/texts/the-portrayal-and-presence-ofthe-body-in-animated-films/ 
Herzog, W. (2010). On the absolute, the sublime, and ecstatic truth. Trans. M. Weigel. Arion, 17(3): 1-12. https://www. bu.edu/arion/files/2010/03/Herzog.pdf

Kadin Cinayetlerini Durduracagiz Platformu. [We Will Stop Femicide Platform] http://www.kadincinayetlerinidurduracagiz. net/for-english

Koentjoro, H. (2019). Tenggerese Horseman [Photograph] Art Limited. $\quad$ https://www.artlimited.net/10711/art/photography-horseman-digital-event-sports/en/318222

Lamb, C. (2019). Our Bodies, Their Battlefields: War Through the Lives of Women. HarperCollins GB.

Meister, S. H. (2004). Michael Wesely: Open Shutter. MoMA Publication.

Niépce, N. J. (1826). View from the Window at Le Gras [Photograph] Wikipedia. https://en.wikipedia.org/wiki/View_from the Window_at_Le_Gras\#/media/File:View_from the Window_at_Le_Gras_colorized_2020_new.png

Pinkola Estés, C. (1989). Women Who Run with the Wolves: Myths and Stories of the Wild Woman Archetype. Ballantine Books.

Schechner, R. (2017). Performance Studies: An Introduction. Taylor and Francis. https://doi.org/10.4324/9780203125168

Titarenko, A. (1993). City of Shadows [Photograph Series]. Alexey Titarenko website. http://www.alexeytitarenko.com/ cityofshadows

Wesely, M. (2004). The Museum of Modern Art [Photograph] MoMA. https://www.moma.org/calendar/exhibitions/119
Wildsound Festival. (2020, December 13). Kam Short Film, Audience Feedback from Dec. 2020 Experimental/Dance/ Music Festival. YouTube video. https://www.youtube.com/

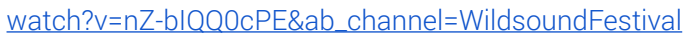

Yalcinalp, E. (2021, March 26). Turkey Erdogan: Women rise up over withdrawal from Istanbul Convention. BBC News. https://www.bbc.com/news/world-europe-56516462 